PERM JOURNAL OF PETROLEUM AND MINING ENGINEERING

ВЕСТНИК ПНИПУ. ГЕОЛОГИЯ. НЕФТЕЕАЗОВОЕ И ГОРНОЕ ДЕЛО

ISSN 2224-9923

Volume / Tom 16 №4 2017

http://vestnik.pstu.ru/geo

УДК 551.242.1:550.348

Article / Статья

(C) PNRPU / ПНИПУ, 2017

\title{
CONNECTIONS BETWEEN INTERMEDIATE \& SHALLOW-FOCUS EARTHQUAKES AND TECTONIC FAULTS BASED ON DATA OF CDP SEISMIC SURVEY METHOD
}

\section{Namaz P. Yusubov}

Azerbaijan National Academy of Sciences. Oil and Gas Institute (9 F. Amirov st., Baku, Azerbaijan, AZ1000)

\section{О СВЯЗЯХ ОЧАГОВ ПРОМЕЖУТОЧНЫХ И МЕЛКОФОКУСНЫХ ЗЕМЛЕТРЯСЕНИЙ \\ С ТЕКТОНИЧЕСКИМИ РАЗЛОМАМИ ПО ДАННЫМ СЕЙСМОРАЗВЕДКИ МЕТОДОМ ОБЩЕЙ ГЛУБИННОЙ ТОЧКИ}

\section{Н.П. Юсубов}

Национальная академия наук Азербайджана. Институт нефти и газа (AZ1000, Азербайджан, г. Баку, ул. Ф. Амирова, 9)

Received / Получена: 24.07.2017. Accepted / Принята: 05.10.2017. Published / Опубликована: 01.12.2017

Key words:

earthquake focus, hypocentre, epicentre, subduction, earth crust, lithospheric plates, shallow-focus earthquakes, intermediate-focus earthquakes, deep-focus earthquakes, continental crust, tectonic energy, well logging, deep seismic sounding (DSS), method of common depth poin (CDP)

Ключевые слова

очаг землетрясения, гипоцентр эпицентр, субдукция, земная кора, литосферные плиты, мелкофокусные землетрясения, промежуточно-фокусные землетрясения глубокофокусные землетрясения, континентальная кора, тектонические разломы зона коллизии, тектоническая энергия, геофизические исследования скважин (ГИС), метод глубинного

сейсмического зондирования (ГС3), метод общей глубинной точки (МОГТ).

\begin{abstract}
The territory of Azerbaijan located in the central part of the Mediterranean mobile belt is characterized by high seismicity, mud volcanism, widespread slumps and contrast character of modern vertical and horizontal movements occurring in the sedimentary part of the geological section.

The paper contains results of studies of the features of the connection of earthquakes and tectonic movements that cover the Mesozoic and Cenozoic intervals of the geological section. The work is carried out with a complex interpretation of data by the method of the common depth point (CDP) of seismic survey; well logging; vertical seismic profiling (VSP) performed on the study area and its periphery; observations of seismic for the period from 2003 to 2016. A comprehensive interpretation of the data allow to construct several seismogeological profiles in a direction perpendicular to the axis of the Caucasian mountain structures. Several profiles of a similar direction (SW-NE) were compiled along the Caspian Sea as well. The geological section is split into stratigraphic and lithologic-facies intervals based on CDP seismic data using VSP and well logging data. Analysis of dynamic and kinematic parameters of the seismic wave field recorded on the area of interest showed that a tectonic process began in the Mesozoic (possibly Paleozoic) period, continued to the end of the Cretaceous, somewhat decreased (unloaded) at the beginning of the Cenozoic and then continued in the Quaternary period. The seismic activity of the region confirms that the process continues nowadays.

Based on the results of a joint interpretation of seismology and CDP seismic survey data it was established that shallow-focus earthquakes in the foothill regions of Azerbaijan occurred and occur under the influence of global tectonic processes that create a prolonged geodynamic tension in the upper part (to the depth of $12 \mathrm{~km}$ ) of the sedimentary complex of deposits. Joint interpretation of CDP seismic survey data and seismology indicates the presence of a collision zone in the area of the junction of the South Caspian depression and Absheron-Pribalkhanskiy threshold, interpreted by some researchers as a subduction zone.

The analysis of geological and geophysical data accumulated during the period from 1985 to 2015 tells about the need to revise the tectonic map of the oil and gas bearing regions of the republic and its connection with the seismic map of the territory.
\end{abstract}

Территория Азербайджана, расположенная в центральной части средиземноморского подвижного пояса, характеризуется высокой сейсмичностью, грязевым вулканизмом, широким развитием оползневых процессов, контрастным характером современных вертикальных и горизонтальных движений, имеющих место в осадочной части геологического разреза.

Статья посвящена результатам исследований особенностей связи землетрясений с тектоническими движениями, охватывающими мезозойский и кайнозойский интервалы геологического разреза. Работа выполнена при комплексной интерпретации данных методом общей глубинной точки (МОГТ) сейсморазведки; геофизических исследований в скважинах (ГИС); вертикального сейсмического профилирования (ВСП), выполненного на площади исследования и ее периферии; сейсмологических наблюдений за период с 2003 по 2016 г. Комплексная интерпретация этих данных позволила построить несколько сейсмогеологических профилей в направлении, перпендикулярном оси Кавказских горных сооружений. Несколько профилей аналогического направления (юго-запад - северо-восток) составлены и по акватории Каспийского моря. Разбиение геологического разреза на стратиграфические и литолого-фациальные интервалы по материалам сейсморазведки МОГТ было выполнено с использованием данных ВСП и ГИС.

Анализ динамических и кинематических параметров сейсмического волнового поля, зарегистрированных в районе исследования, показал, что напряженность тектонического процесса, начавшегося в мезозое (возможно палеозое), продолжалась до конца мела, несколько уменьшилась (разгрузилась) в начале кайнозоя и затем продолжилась в четвертичном периоде. Сейсмическая активность региона свидетельствует о продолжении процесса и в настоящее время. По результатам совместной интерпретации данных сейсмологии и сейсморазведки МОГТ установлено, что мелкофокусные землетрясения в предгорных районах Азербайджана происходили и происходят под влиянием глобальных тектонических процессов, создающих продолжительную геодинамическую напряженность в верхней части (до глубины 12 км) осадочного комплекса отложений. Совместная интерпретация данных сейсморазведки МОГТ и сейсмологии указывает на наличие в зоне сочленения Южно-Каспийской впадины и АбшероноПрибалханского порога зоны коллизии, интерпретируемой некоторыми исследователями как зона субдукции.

Анализ накопленного в период с 1985 по 2015 г. геологического и геофизического материала указывает на необходимость пересмотра тектонической карты нефтегазоносных районов республики и ее связи с картой сейсмичности территории.

Namaz P. Yusubov - Doctor of Geology and Mineralogy, Head of the Department of Deep Geophysics (tel.: +994 12429 95 85, e-mail: nyusubov@gmail.com).

Юсубов Намаз Пути оглы - доктор геолого-минералогических наук, руководитель отдела геофизики больших глубин (тел.: +994 124299585 , е-таil: nyusubov@gmail.com) 


\section{Introduction}

A lot of studies was devoted to the study of the connection between the earthquakes that occurred in Azerbaijan and active tectonic zones on the basis of a joint interpretation of deep seismic sounding (DSS), correlation method of refraction waves (CMRW) and seismic observations data.

Seismic zonation maps of the territory of Azerbaijan are built periodically (1957, 1963, $1965,1968,1980,1989)$ using data from the DSS and CMRW, results of generalization of various geological and seismic information. The main result of that studies is the fact that focuses of earthquakes have direct links with tectonic discontinuities. Data on this issue of Azerbaijani researchers is available on the website of the Institute of Geology and Geophysics of the National Academy of Sciences of Azerbaijan. It is believed that faults are weakened sections of the earth's crust, along which the accumulated elastic energy is discharged sometimes.

The brief overview above shows that the idea of connecting earthquake focuces with tectonic faults is supported by many specialists including foreign ones [1-3]. According to the hypothesis of tectonics of lithospheric plates (mobilism), the statement is correct $[4,5]$. But there are no tectonic plates or blocks on the territory of Azerbaijan on the contacts of which there would be earthquake focuses. In addition, according to the table borrowed from [5] with the addition, and the catalog [6], mostly shallow and rarely intermediate-focus earthquakes occur. The last are generally observed in the Caspian sector of Azerbaijan and zones adjacent to that.

Distribution of earthquakes by depths

\begin{tabular}{|l|c|c|c|}
\hline \multicolumn{1}{|c|}{ Title } & $\begin{array}{c}\text { Depth range, } \\
\mathrm{km}\end{array}$ & $\begin{array}{c}\text { In the } \\
\text { world, } \\
\%\end{array}$ & $\begin{array}{c}\text { In Azerbaijan } \\
(2003-2016), \%\end{array}$ \\
\hline Shallow-focus & $h<60$ & 80 & $95^{*}$ \\
\hline Intermediate-focus & $60<h<150$ & 15 & $5(0.2)$ \\
\hline Deep-focus & $h>150$ & 5 & 0 \\
\hline
\end{tabular}

Note: * - taking into account the number of weak earthquakes for 2006-2010

Comparison of results and conclusions of previous studies with the map (Fig. 1) of the distribution of epicenters (characterized by mosaicism) of earthquakes that occurred over the period 2003-2016 shows that there is no singlevalued connection between their centers with known (or suspected) tectonic faults. It is obvious from the Fig. 1 that epicenters of earthquakes occupy the areas located along the lines of tectonic faults, characterized mainly by a subvertical structure. The depths of hypocenters and plane of discontinuities are also not comparable. The conclusion was obtained taking into account all the parameters (displacement amplitude, slope of the plane, penetration depth of the rupture etc.) of disjunctive and plicative dislocations.

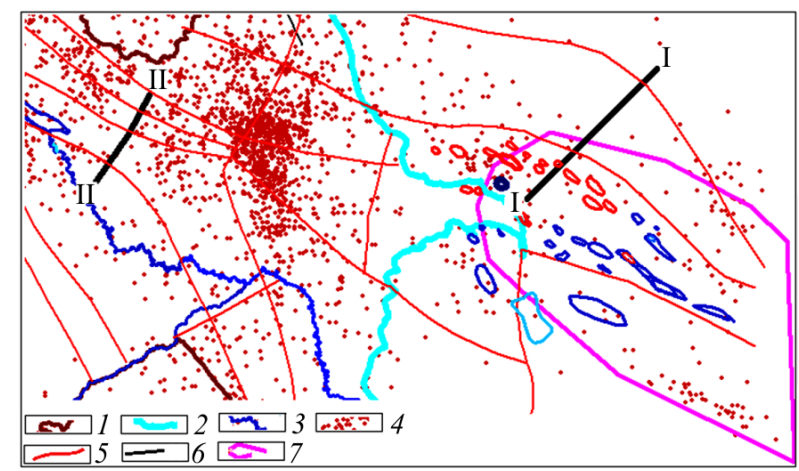

Fig. 1. Map of the location of tectonic lines and epicenters of earthquakes (according to the data of the seismic service for 2003-2016). Scale: 1: 700 000: 1 - a state border; 2 - a coastal line of the Caspian Sea; 3 - the channel of the Kura and Araks rivers; 4 - epicenters of earthquakes; 5 - lines of tectonic faults, ruptures and flexures; 6 - lines of seismic profiles; 7 - a zone of assumed subduction

\section{On the intermediate-focus and shallow-focus earthquakes}

At first glance the results of [7-16] allow finding the indirect connection between focuses of intermediate and deep-focus earthquakes with deep tectonic faults, but having such a conclusion not confirmed by real data.

Especially note the author's conclusion [7] on the subduction origin of earthquake focuses in the Southern Caspian. The author of the paper divides the study area into three conventional blocks such as Kavkaz-Talyshskiy and Kopetdag-Turanskiy boundary and middle, related to the Caspian and mountain structures of Elbrus. He proposes a hypothesis that the blocks under geodynamic pressure are deformed and thickened, creating mountain structures. At the same time, the part of the oceanic crust of the Southern Caspian, which is not subject to folding, is experiencing pressure from Elbrus, plunges under the continental crust of the Scythian-Turan plate in the central part of the Caspian Sea, along the entire Cheleken- 
Absheron threshold. The continental crust of the North Caspian, which is involved in movement along the subduction zone, undergoes bending and stretching in its upper part. As a result, tectonic movements of the fault type are formed. That is cofirmed by the mechanism of seismic focuses in the subduction zone. At the same time, the author of [7] does not consider the relationship between the blocks. For example, in order to fulfill the required conditions between the blocks there must be slip planes ensuring free movement of blocks crossing the layers of the sedimentary complex and deeper. It seems to us that the events supposed by the author could occur when those blocks are separated with tectonic gaps with several hundred kilometer in length, and they should cover the entire lithosphere. There are no such studies at all in the study area. The authors of [8-16], citing each other, also note the connection of earthquake focuses and that subduction zone.

Other interesting results of the study are discussed in [12]: "... Many scientists came to the conclusion that the oceanic lithosphere of the South Caspian basin underlays the Elbrus mountain structures framing the hollow. During the Eocene powerful volcanic eruptions occurred in the Elbrus mountain system. They are apparently related to the subduction processes of the slab of the South Caspian Sea. Occurence of Late Miocene to Quaternary volcanism is also noted by the researchers. Structural studies in the northern part of Elbrus suggest that the faults on its border with the South Caspian depression are compression associated with the underthrust of the Southern Caspian under Elbrus. The data of focal mechanisms of focuses of earthquakes indicate mainly the northeastern orientation of the compression axes. The huge sedimentary stratum in the South Caspian depression apparently strengthened the plunging and underthrust of the basin. The geophysical data given here also indicate the processes of subduction ..." .

It should be noted that all the conclusions in those papers were obtained mainly from the data of gravimetric studies performed on a regional scale.

The authors of [12] believe that, in addition to numerous crustal earthquakes, upper mantle earthquakes are recorded here. The maximum depth of earthquakes in the Absheron threshold reaches $90-100 \mathrm{~km}$.
However, according to the data of the Seismological Service of Azerbaijan, the epicenters of about 50 shallow and intermediatefocus earthquakes fall into the subduction zone supposed in [7-16] (see Fig. 1). They are dispersed on an area of about $22,000 \mathrm{~km}^{2}$ with no regularity and are divided into two groups. The depths of the first group of hypocenters range from $20-60 \mathrm{~km}$, in the second group they have values of $30-70 \mathrm{~km}$.

Note that depths of focuses of that earthquakes are determined by the indications of seismic stations of the far zone (there are none in the Caspian Sea) and along a vertical hodograph with certain errors. Taking into account that errors the depths could be reduced in approximately 1.52.0 times. The correctness of this conclusion is proved in the following parts of the preset paper.

Further in work [12] it is noted that the Caspian Sea crosses from north to south a series of latitudinal structural zones of the southeastern edge of the ancient (Precambrian) East European platform, young (epichercian) Scythian-Turanian platform and modern Alpine-Himalayan orogenic belt. Thickness of the sedimentary cover in the South Caspian basin, which is the southern half of this sea, reaches $25 \mathrm{~km}$. The authors do not cite the reference data (there are numerous scientific and research works devoted to this problem in the references) claim that a part of that $10-\mathrm{km}$ thickness is composed of Pliocene-Quaternary deposits. There are below clay Miocene and Oligocene deposits are widly spread, which the roots of mud volcanoes are connected with. According to the authors of [12], in the section of the South Caspian basin there is a waveguide (that can be seen from the Fig. 2, cited in the article), rising to the earth's surface in the Absheron region and submerging under the chain of Elbrus. Reduced values of seismic velocities in the upper horizons of the crust and intensive development of mud volcanism are associated with the waveguide roof elevation (to the surface). It is likely that the fluids are squeezed along the waveguide up. That leads to the development of intense mud volcanism here. In the opinion of the authors, the assumption that deep layers participate in the feeding of mud volcanoes is confirmed by the fact that mud volcanoes carry to the surface fragments of chalky rocks that occur much lower than the accumulations formed during the epoch of avalanche sedimentation, traditionally considered 
as a source of mud volcanism. Let us note following: 1. According to Azerbaijan researchers (including the author of the article), fragments of Mesozoic deposits, found sometimes in products of mud volcanoes, are allochthons, i.e. they fell into their root areas from the elevated part of the basin as a result of landslide or mudflow processes. 2. On the line of the profile given in the work up to the Absheron threshold there are several lines where there are mud volcanoes, which by the number and intensity of occurence far exceed those in the Absheron threshold area. 3. Roots of the mud volcanoes that exist in the land and sea areas of Azerbaijan are associated with the Miocene (more specifically with Maikop) sediments $[17,18]$.

There is none epicenter, i.e. earthquake in the central part of the subduction zone, which is mentioned in [7-11, 13-16]. For this reason, the focal zones of earthquakes that occurred on this territory are almost impossible to connect with the subduction process. Besides, comparison points to the difference between stretch lines of the proposed subduction, according to the data mentioned above, which prooves the subjectivity of opinions about the presence of a subduction zone here (a hypothetical assumption). In addition, the CDP seismic data shows $[19,20]$ that along the line of a group of faults extending along the NorthAbsheron syncline, the south-western layers of the crust overthrust the northeastern one on contrary by $180^{\circ}$ (Fig. 2).

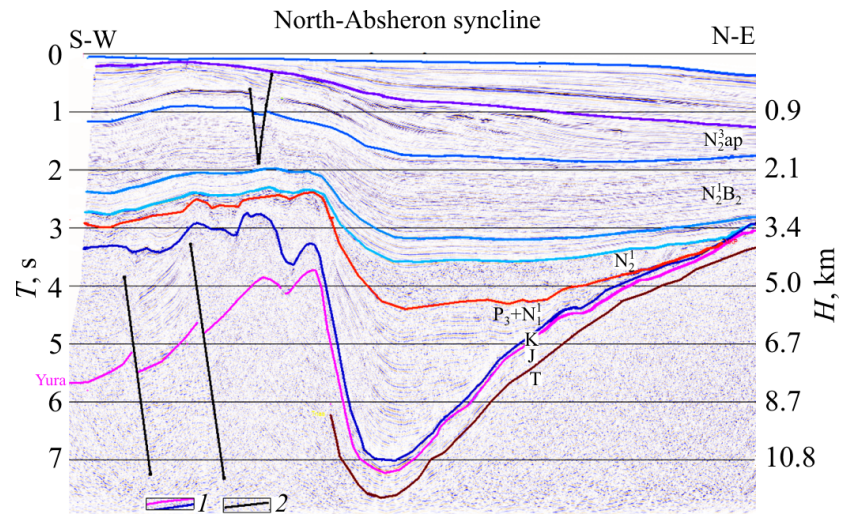

Fig. 2. Seismic time section I-I (see Fig. 1). Kinematic and dynamic features of the reflected wave field indicate that the area where the seismic profile line is located in the zone of tectonic tension: 1 - surfaces of erosion of stratigraphic units according to the data of vertical seismic profiling, deep drilling and CDP seismic survey; 2 - tectonic faults; $T$-double time, s; $H$ - depth, $\mathrm{km}$
Analysis of dynamic and kinematic parameters of the seismic wave field, performed by us, shows that the intensity of the tectonic process that began in the Mesozoic (possibly Paleozoic) continued to the end of the Cretaceous, somewhat decreased (unloaded) at the beginning of the Cenozoic and continued in the Quaternary period (Fig. 3). Seismic activity of the region indicates that the process continue today. In other words, the seismic data of the CDP method indicates the presence of a zone of collision, interpreted as a subduction zone by researchers, as it seems to us, unfamiliar with the results of seismic prospecting (2003-2016).

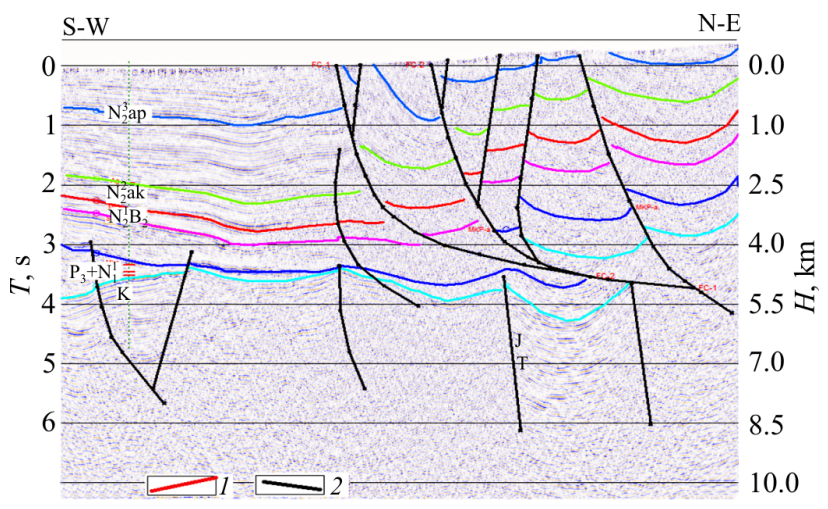

Fig. 3. Seismic geological profile II-II (see Fig. 1 and 2): 1 - surfaces of erosion of stratigraphic units according to the data of vertical seismic profiling, deep drilling and CDP seismic survey; 2 - tectonic faults

The same conclusion was obtained by the authors of [21] based on results of geological interpretation of more accurate seismic data accumulated mainly in the recent period. One of the main conclusions of [21] is as follows: seismological data do not show geological, geophysical and seismological signs of subduction of the South Caspian Basin (SCB) crust under the edge of the epihercine platform in the zone of junction of the SCB and Absheron-Pribalkhan threshold.

It should be noted that geological and geophysical data indicate that geodynamic processes continue and cause the geological section to deform (see Fig. 2 and 3). The study of this process should be continued on the basis of modern geophysical information, primarily seismic exploration (CDP, CMRW).

While searching for evidence of the direct connection of shallow-focus earthquakes with tectonic faults, a researcher also faces the problem 
of determining the specific location of the focus of tectonic energy release in a real three-dimensional geological environment. It should be noted that the weight of shallow-focus earthquakes is about $95 \%$ of the total number of earthquakes that occurred in the Azerbaijan during the period from 2003 to 2016.

Usually, there is no tectonic fault at the geologic section of zones of location of epicenters (focuses) of earthquakes or there is a difference of 10 kilometers between the coordinates of epicenters (or hypocenters) of earthquakes and fault lines observed. It is also interesting that in many cases the earthquake hypocenters having very close values for the $\mathrm{X}$ and $\mathrm{Y}$ coordinate axes $(0.2-2.0 \mathrm{~km})$ differ significantly along the $\mathrm{Z}$ axis (3-6 km). It should be emphasized that the conclusion was obtained on the basis of the author's research and supplemented with the results of an analysis of published works [6], [20], tectonic maps and maps of distribution of earthquake epicenters, refers more to shallowfocus earthquakes.

Recent studies [20] have shown that in some cases, due to the incorrect choice of a model for the interpretation of geophysical fields, especially gravimetric, inaccurate ideas about the tectonic structure of individual territories of Azerbaijan were formed. According to the authors of the papers $[1,22-25]$, the presence of individual maximum against the background of a regional minimum of gravity and other geological factors indicate the presence of a number of deep faults forming a wide disjunctive zone in the territory of Azerbaijan. However, in [20], using 2D and 3D-seismic data with the method of CDP, it was shown that in place of the West Caspian deep fault (amplitude up to $1.5 \mathrm{~km}$ ) indicated on the previously constructed tectonic maps using data of DSS-CMRW and gravimetric surveys, there is a flexure with an amplitude of about $5.6 \mathrm{~km}$.

The distance between the lowered and raised wings of this flexure in horizontal plane reaches 25 $\mathrm{km}$. The slope of its closing element is $\approx 14-25$ degrees. In other words, that flexure is the northeastern board of the Saatly-Geokchay zone of uplifts, which in the area of the riverbed of Girdimanchay changes the direction of the strike to the north-west and continues along the AlazanoAlyatsky fault. Flexure is located at a distance $\approx 5$ $\mathrm{km}$ northeast of the fault line shown on tectonic maps. There is no previously supposed flexure on the continuation of the West Caspian deep fault in the Caspian-Gubinsk lowland.

\section{Processes in the geological environment of the study area}

The Fig. 3 represents one of the seismic geological profiles, which is compiled using geological and geophysical information. It is seen from the figure that the zone of formation disturbance covers a wide area on the surface of the Earth (the right-hand side of the Fig. 3) and within the geological section of the sedimentary complex of deposits.

Tectonic faults located below the surface of the Mesozoic (seismic level $\mathrm{K}$ ) have a small amplitude. Their shear planes have a vertical or subvertical orientation. They do not continue (do not migrate) to the upper level of the geological section, which is a direct evidence of their inactivity during the Cenozoic period. It seems to us that in the region of interest they were formed at the end of the Cretaceous and this process was completed in Early Paleogene. In other words, they did not develop in the late Alpine stage of the formation of the Caucasus on the territory in question. At the same time, we observe the continuation of formation of belts of the folded structure along the Cenozoic section interval according to seismic data of the CDP, with the reduction of space in a wide band. Fault planes come to the surface of the Earth, which indicates the young (modern) age of the tectonic processes that occurred there. It is clear according to the Fig. 4 that due to movements along longitudinal faults and overthrusts the relief of the studied area is complicated by young local uplifts forming a series of parallel ridges.

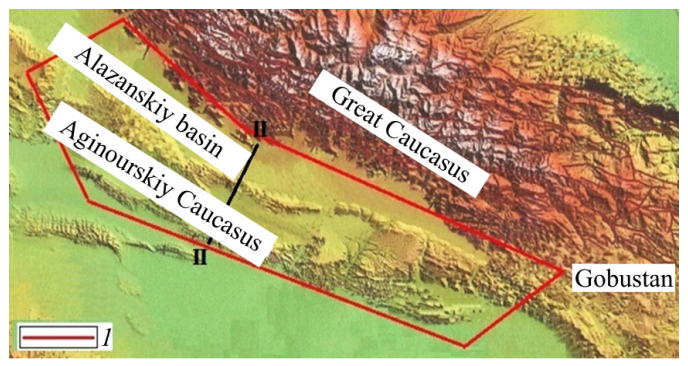

Fig. 4. Relief map of the studied area: 1 - outline of the studied area

The faults observed along the Cenozoic floor (see Fig. 3) do not intersect the Mesozoic interval of the 
section. It means that they are located only at the level of the Cenozoic deposits and along their displacement plane the northeastern part of the sedimentary cover approaches (slips) to the southwest one. There is an increase in the angles of the inclination of the fault displacement planes to the north-eastern part of the section and the region characterized by thrust processes begins. The length of fault lines within the studied area reaches $150 \mathrm{~km}$.

The same for the central part of the seismic section (see Fig. 3) along the Cenozoic floor. The Mesozoic deposits are deep enough. At the end of the section the surface of erosion of the Mesozoic deposits gets a concave shape. There are uplifts formed along the planes of which the Mesozoic part begins to approach the Cenozoic interval of the section. According to the data of geology and seismic surveys (parallel to the line II-II seismic profiles), such a tectonic structure characterizes the territory in southeastern part of which there is the area of study with length of more than 300 and width of about $30 \mathrm{~km}$.

It should be noted that there are faults with slip planes of vertical, subvertical and horizontal directions. It is noteworthy that sometimes a fault is characterized by all three elements at the same time. The descriptions of features of the geological structure of the area of interest allows to conclude that earthquake focuses are formed within the interval of the sedimentary cover whose thickness reaches approximately $15 \mathrm{~km}$. In other words, they are formed as a result of the pushing of one mass to the other along the planes (see Fig. 2 and 3), which has an inclined or subvertical direction, cover vast territories. Sometimes mass movement occurs along contacts [26] of younger and more competent breeds (for example, between the surface of the Mesozoic erosion and the Cenozoic base). For this reason, direct connections between the coordinates of earthquake focuses with fault lines are not observed. This conclusion is confirmed by the data of seismological observations, according to which the epicenters of more than $68 \%$ of the earthquakes that occurred there are at depths of down to $22 \mathrm{~km}$, and this zone has a width of more than $30 \mathrm{~km}$ across the Earth's surface. The discrepancy between certain depths of the hypocenters at close values of the coordinates of their epicenters is explained by "multifloor" blocks, separated by faults (see Fig. 3)

It should be noted that the velocity model of the medium used in determining the parameters of earthquakes differs from that calculated by us using VSP data, on which deep seismogeological sections are constructed. A comparison of these curves is shown in Fig. 5. Calculations show that if this difference is taken into account then more than $90 \%$ of earthquake focuses will move to a depth of less than $15 \mathrm{~km}$, which corresponds to thickness of the sedimentary cover. Similar conclusions were obtained from the results of [26], where the seismicity features of other oil and gas regions of Azerbaijan are stuied. Those conclusions and the results of [27] confirm the expediency of using the velocity model shown in the Fig. 5.

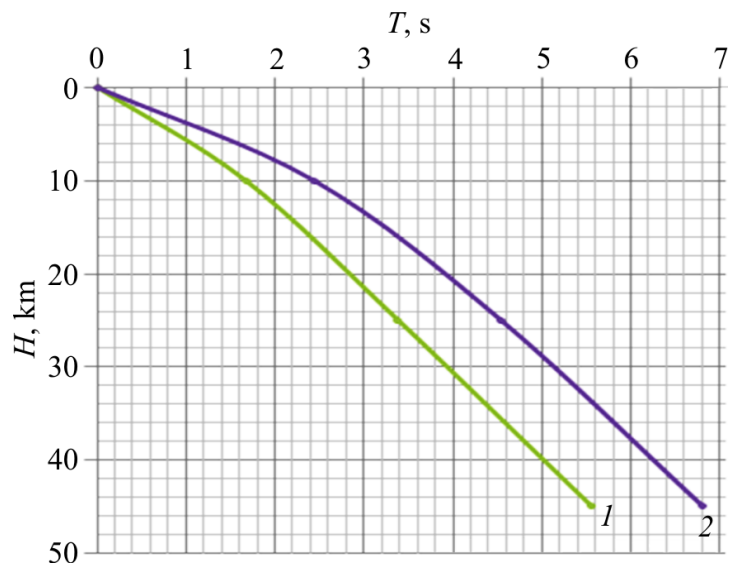

Fig. 5. Vertical hodographs: 1 - used in determining the depth of the source (hypocenters) of earthquakes; 2 - calculated using the VSP data

How are the earthquake focuses formed in the area of study? The answer to this question was proposed in [28], where, in accordance with the results of a study by L.M. Rastsvetaeva [29] as a result of study of structural parageneses of discontinuous structures together with geophysical data, the main faults of the Greater Caucasus are interpreted as subvertical, extending to depth of 60$80 \mathrm{~km}$. One of the important conclusions of this work is as follows: the folding for the Greater Caucasus occurs with a reduction in space, but the reduction itself can arise due to the fact that rocks of the lower levels of the continental crust substantial immerse and acquire the properties of mantle rocks. There is a conceptual profile through the Great Caucasus is shown in [28], reflecting the subduction of the Transcaucasian plate under the Greater Caucasus. On this profile [28], the main gentle impinging surface is shown at a depth of $5-10 \mathrm{~km}$.

Results of our studies based on modern seismic materials (see Fig. 4) confirm the conceptual geological model of the region presented on this 
profile. However, in the area of study there are no faults extending to a depth of $60-80 \mathrm{~km}$, as suggested in [28]. According to the Fig. 3 the structure of the upper part of the geological section allows the fulfillment of the necessary conditions under which the movement of its blocks becomes quite possible [30-32].

It should be noted that the reasons for some horizontal displacements of the Earth's surface, detected by GPS measurements [33], explain the seismic section shown in the Fig. 3.

Analysis of the dynamic and kinematic parameters of the wave field from seismic data shows that the condensation of epicenters of earthquakes and their maximum intensity correspond basically to the areas of conjugation of the newest structures, i.e. zones of contrasting movements and contrast relief. Epicenters of earthquakes are confined to the boundary of the regions of uplifts and relative subsidence. They are located along the axis of the mountain structure of the Greater Caucasus. At the same time, the epicenters of the earthquakes shown in the map of Fig. 1 are distributed in a mosaic pattern. It seems to us that this is connected to: a) errors in the calculation of coordinates ( $X$ and $Y$ ) epicenters (according to published materials, the calculated errors range within $\pm 10 \mathrm{~km}$ ); b) coverage of tectonic events of a vast space. A clear proof of the last conclusion is one of the numerous seismogeological profiles, shown in the Fig. 3.

\section{Conclusions}

1. More than $90 \%$ of earthquakes on the area of interest occurred at the depth of less than $15 \mathrm{~km}$, which corresponds to thickness of the sedimentary complex of sediments.

2. Earthquakes in the area of interest are formed as a result of overthrusting of one mass to another along planes having an oblique or subvertical direction covering a territory of $300 \times 30 \mathrm{~km}$.

3. Condensations of hypocenters of earthquakes and their maximum intensity in the study area correspond basically to the areas of conjugation of the newest structures formed as a result of underthrusting of the Transcaucasian plate to Greater Caucasus.

4. The CDP seismic survey data indicate the zone of collision along the Severo-Absheron syncline interpreted by some researchers as a subduction zone.

5. An analysis of geological and seismic data accumulated during the period from 1985 to 2015 points to the need to revise the tectonic map of oil and gas areas and its connection with the seismic map of republic's territory.

\section{References}

1. Gadzhiev R.M. Glubinnoe geologicheskoe stroenie Azerbaidzhana [Deep geological structure of Azerbaijan]. Baku, Azgosizdat, 1965, 200 p.

2. Aki K., Richarde P. Kolichestvennaia seismologiia. Toriia i metody [Quantitative seismology. Theory and methods]. Moscow, Mir, 1983, vol. 1, 510 p.

3. Bullen K.E. On strain energy in Earth's upper mantle. Transactions, American Geophysical Union, 1953, vol.34, no.1, pp.107-116. DOI: 10.1029/TR034i001p00107

4. Zonenshain L.P., Kuz'min M.I., Natalin L.M. Tektonika litosfernykh plit territorii SSSR [Tectonics of lithospheric plates of the territory of the USSR]. Moscow, Nedra, 1990, vol.2, 327 p.

5. Prichiny vozniknoveniia zemletriasenii i posledstviia. Priroda zemletriasenii [Causes of earthquakes and consequences. The nature of earthquakes], available at: fb.ru/ article/178750/prichinyi-...11.04.15] (accessed 15 May 2017).

6. Katalog seismoprognosticheskikh nabliudenii na territorii Azerbaidzhana za 2006-2010 gg. [Catalog of seismic prediction observations on the territory of Azerbaijan for 2006-2010]. Baku, ELM, 2011, 210 p.

7. Ob"emnaia seismogeodinamicheskaia model' Kaspiiskogo regiona [Volumetric seismic geodynamic model of the Caspian region], available at: http://seismosu.ifz.ru/personal/caspiy.htm (accessed 15 May 2017).

8. Mamedov P.Z. Osobennosti stroeniia zemnoi kory IuKMV [Features of the structure of the Earth's crust YuKMV]. Geologiia Azerbaidzhana. Neft' i gaz, 2008, vol.VII, pp.9-103.

9. Knapp J.H., Diaconesccu C.C., Connor J.A., Mcbride J.H., Simmons M.D. Deep seismic exploration of the South Caspian Basin: Litospheric-scale imaging of the world's deepest basin. AAPG's Intern. regional conf. Abstr. Istanbul, 2000, pp.35-37. DOI:10.1306/1205831St553248

10. Morfostruktura, noveishaia tektonika i seismika na Kavkaze [Morphostructure, the latest tectonics and seismic in the Caucasus], available at: kmvline.ru/lib/kavkaz/4.php (accessed 15 May 2017).

11. Granath J.W., Soofi R.F., Baganaz O.W., Bagirov E., Gravity modeling and its implikations to the tectoniks of the South Caspian basin. Oil and gas of the Greater Caspian area: $A A P G$ Studies in Geology. Ed. by P.O. Yilmaz, G.H. Isaksen. 2007, 55, p.43-46. DOI: 10.1306/1205832St55854

12. Model' glubinnogo stroeniia Iuzhno-Kaspiiskoi vpadiny [Model of the deep structure of the South Caspian basin], available at: wdcb.ru/sep/sedimentary_basins/Caspsea/ models/SCasp_mod.ru.html (accessed 15 May 2017). 
13. Ashkhabadskoe zemletriasenie 1948 goda [Ashgabat earthquake of 1948], available at: olegyakupov.com» blogblog/?p=1232 (accessed 15 May 2017).

14. Granath J.W., Soofi 1 K.A., Baganz O.W., Bagirov E. Gravity modeling and its implications to the tectonics of the South Caspian Basin. AAPG's Intern. regional conf. Turkey, 2000, pp.46-50.

15. Jackson J.A., Priestley E., Allen M. Active tectonics of the South Caspian Basin. Centr. Asia Proj. Rep., 2001, vol.17, pp.45. DOI: 10.1046/j.1365-246X.2002.01005.x

16. Priestley K., Patt on H., Schultz C. Modeling anomalous surface-wave propagation across the South Caspian Basin. Bull. Seismol. Soc. Amer., 2001, vol.91 (6), pp.1924-1929. DOI: 10.1785/0120010118

17. Iakubov A.A., Alizade A.A., Zeinalov M.M. et al. Griazevye vulkany Azerbaidzhanskoi SSR [Mud volcanoes of the Azerbaijan SSR]. Baku, ELM, 1971, 256 p.

18. Iusubov N.P., Kuliev I.S. Seismicheskaia model' griazevulkanicheskoi sistemy [Seismic model of mud volcanic system]. ANKh, 2011, no.3, pp.12-20.

19. Iusubov N.P., Guliev G.A., Borovikova A.Iu., Akhmedov R.L. Glubinnoe stroenie osadochnogo chekhla Severo-Absheronskoi zony podniatii i perspektivy ee neftegazonosnosti po dannym seismorazvedki [Deep structure of the sedimentary cover of the North Absheron uplift zone and the prospects of its oil and gas potential according to seismic data]. ANKh, 2013, no.10, pp.9-15.

20. Iusubov N.P. K voprosu o sushchestvovanii Zapadno-Kaspiiskogo razloma [To the question of existence of the West Caspian fault]. ANKh, 2017, no.4, pp.12-17.

21. Mamedli T.Ia., Rogozhin E.A. O tektonicheskom kharaktere zon sochleneniia zemnoi kory IuzhnoKaspiiskoi vpadiny i Skifsko-Turanskoi plity po dannym seismologii [Tectonic character of the zones of articulation of the Earth's crust of the South Caspian Depression and Scythian-Turan plate according to seismology data]. Voprosy inzhenernoi geologii, 2016, vol.43, no.2, pp.5-16.

22. Kerimov K.M., Novruzov A.K., Daneshvar S.N. Glubinnye razlomy i nekotorye osobennosti razmeshcheniia neftegazovykh mestorozhdenii v Iuzhno-Kaspiiskoi megavpadine [Deep faults and some peculiarities of location of oil and gas deposits in the South Caspian megabasin]. Bakl universitetinin xabarlari, 2012, no.3, pp.69-78.

23. Metaksas Kh.P., Rzaev A.G., Isaeva M.I. Parametry seismicheskoi opasnosti ShamakhyIsmaillinskoi ochagovoi zony zemletriasenii [Parameters of seismic hazard of Shamakhy-Ismayillinskoy focal zone of earthquakes]. Katalog seismoprognosticheskikh nabliudenii na territorii Azerbaidzhana, 2011, pp.314-321.

24. Agaev V.B., Guseinov G.M., Balamedov Sh.R., Amirov E.F. Kaspii: proiskhozhenie, geodinamika i stratigrafiia [Caspian: Origin, geodynamics and stratigraphy]. Bakl Universitetinin Xabarlari, 2006, no.1, pp.86-101.

25. Glumov I.F., Malovitskii Ia.P., Novikov A.A., Senin B.V. Regional'naia geologiia i neftegazonosnost' Kaspiiskogo moria [Regional geology and petroleum potential of the Caspian Sea]. Moscow, NedraBiznestsentr, 2004, 342 p.

26. Iusubov N.P. Osobennosti seismichnosti neftegazovykh oblastei Azerbaidzhana [Features of seismicity of oil and gas regions of Azerbaijan]. Geofizika, 2012, no.2, pp.48-53.

27. Burmin V.Iu., Shmeleva I.B., Fleifel' L.D. et al. Predvaritel'nye rezul'taty peresmotra seismologicheskikh dannykh Kavkaza [Preliminary results of the revision of seismological data of the Caucasus], available at: ifz.ru〉fileadmin/user_upload/subdivisions/506/... (accessed 15 May 2017).

28. Iakovlev F.L. Vladimir Vladimirovich Belousov i problema proiskhozhdeniia skladchatosti [Vladimir Vladimirovich Belousov and the problem of origin of folding]. Geofizicheskie issledovaniia, 2008, vol.9, no.1, pp.53-73.

29. Rastsvetaev L.M., Marinin A.V. Sootnoshenie poverkhnostnoi i glubinnoi struktury severo-zapadnogo Kavkaza [Correlation of the surface and deep structure of the northwestern Caucasus], available at: resources.krc. karelia.ru/krc/doc... (accessed 15 May 2017).

30. Daly M.C. Correlations between Nazca/Farallon Plate kinematics and forearc basin evolution in Ecuador. Tectonics, 1989, 8, no.4, pp.769-790. DOI: 10.1029/TC008i004p00769

31. Seist E.L., Childs J.R., Scholl D.W. The origin of summit basins of the Aleutian Ridge: implications for block rotation of an arc massif. Tectonics, 1988, 7, no.2, pp.327-341. DOI: 10.1029/TC007i002p00327

32. Nur A., Ron H., Scotti O. Fault mechanics and the kinematics of block rotation. Geology, 1986, 14, pp.746749. DOI: 10.1130/0091-7613(1986)14<746:FMATKO >2.0.CO;2

33. Kadirov F.A., Floyd M., Reilinger R., Alizadeh Ak.A., Guliyev I.S., Mammadov S.G., Safarov R.T. Activegeodynamics of the Caucasus region: implications for earthquake hazard assessment in Azerbaijan. Proc. of Azerbaijan National Academy of Sciences. The Sci. of Earth, 2015, no.3, pp.3-17.

\section{Библиографический список}

1. Гаджиев Р.М. Глубинное геологическое строение Азербайджана. - Баку: Азгосиздат, 1965. - 200 с.

2. Аки К., Ричарде П. Количественная сейсмология. Теория и методы. Т. 1: пер. с англ. - М.: Мир, 1983. $-510 \mathrm{c}$

3. Bullen K.E. On strain energy in Earth's upper mantle // Transactions, American Geophysical Union. - 1953. - Vol. 34, № 1. - P. 107-116. DOI: 10.1029/TR034i001p00107

4. Зоненшайн Л.П., Кузьмин М.И., Наталин Л.М. Тектоника литосферных плит территории СССР. - М.: Недра, 1990. - Т. 2. - 327 с.
5. Причины возникновения землетрясений и последствия. Природа землетрясений [Электронный pecypc]. - URL: fb.ru/article/178750/prichinyi-...11.04.15 (дата обращения: 15.05.2017).

6. Каталог сейсмопрогностических наблюдений на территории Азербайджана за 2006-2010 гг. - Баку: ELM, 2011. - 210 c.

7. Объемная сейсмогеодинамическая модель Каспийского региона [Электронный ресурс]. - URL: http://seismos-u.ifz.ru/personal/caspiy.htm (дата обращения: 15.05.2017). 
8. Мамедов П.З. Особенности строения земной коры ЮКМВ // Геология Азербайджана. Нефть и газ. 2008. - T. VII. - C. 9-103.

9. Deep seismic exploration of the South Caspian Basin: Litospheric-scale imaging of the world's deepest basin / J.H. Knapp, C.C. Diaconesccu, J.A. Connor, J.H. Mcbride, M.D. Simmons // AAPG's Intern. regional conf.: Abstr, Istanbul, Turkey, July 9-12, 2000. - Istanbul, 2000. - P. 35-37. DOI:10.1306/1205831St553248

10. Морфоструктура, новейшая тектоника и сейсмика на Кавказе [Электронный ресурс]. - URL: kmvline.ru/lib/kavkaz/4.php (дата обращения: 15.05.2017).

11. Gravity modeling and its implikations to the tectoniks of the South Caspian Basin / J.W. Granath, R.F. Soofi, O.W. Baganaz, E. Bagirov; ed. by P.O. Yilmaz, G.H. Isaksen // Oil and gas of the Greater Caspian area: AAPG Studies in Geology. - 2007. - 55. - P. 43-46. DOI:10.1306/1205832St55854

12. Модель глубинного строения ЮжноКаспийской впадины [Электронный ресурс]. - URL: wdcb.ru/sep/sedimentary_basins/Caspsea/models/SCasp_ mod.ru.html (дата обращения: 15.05.2017).

13. Ашхабадское землетрясение 1948 года [Электронный ресурс]. - URL: olegyakupov.com〉 blogblog/?p=1232 (дата обращения: 15.05.2017).

14. Gravity modeling and its implications to the tectonics of the South Caspian Basin / J.W. Granath, K.A. Soofil, O.W. Baganz, E. Bagirov // AAPG's Intern. Regional Conf. - Turkey, 2000. - P. 46-50.

15. Jackson J.A., Priestley E., Allen M. Active tectonics of the South Caspian Basin // Centr. Asia Proj. Rep. - 2001. Vol. 17. - P. 45. DOI: 10.1046/j.1365-246X.2002.01005.X

16. Priestley K., Patt on H., Schultz C. Modeling anomalous surface-wave propagation across the South Caspian Basin // Bull. Seismol. Soc. Amer. - 2001. Vol. 91 (6). - P. 1924-1929. DOI: 10.1785/0120010118

17. Грязевые вулканы Азербайджанской ССР / А.А. Якубов, А.А. Ализаде, М.М. Зейналов [и др.]. Баку: ЭЛМ, 1971. - 256 с.

18. Юсубов Н.П., Кулиев И.С. Сейсмическая модель грязевулканической системы // АНХ. - 2011. № 3. - С. 12-20.

19. Глубинное строение осадочного чехла СевероАбшеронской зоны поднятий и перспективы ее нефтегазоносности по данным сейсморазведки / Н.П. Юсубов, Г.А. Гулиев, А.Ю. Боровикова, Р.Л. Ахмедов // АНХ. - 2013. - № 10. - С. 9-15.

20. Юсубов Н.П. К вопросу о существовании ЗападноКаспийского разлома // АНХ. - 2017. - № 4. - С. 12-17.

21. Региональная геология и нефтегазоносность Каспийского моря / И.Ф. Глумов, Я.П. Маловицкий, А.А. Новиков, Б.В. Сенин. - М.: Недра-Бизнесцентр, 2004. $-342 \mathrm{c}$.
22. Мамедли Т.Я., Рогожин Е.А. О тектоническом характере зон сочленения земной коры ЮжноКаспийской впадины и Скифско-Туранской плиты по данным сейсмологии // Вопросы инженерной геологии. - 2016. - Т. 43, № 2. - С. 5-16.

23. Керимов К.М., Новрузов А.К., Данешвар С.Н. Глубинные разломы и некоторые особенности размещения нефтегазовых месторождений в ЮжноКаспийской мегавпадине // Bak1 universitetinin xəbərləri. - 2012. - № 3. - C. 69-78.

24. Метаксас Х.П., Рзаев А.Г., Исаева М.И. Параметры сейсмической опасности ШамахыИсмаиллинской очаговой зоны землетрясений // Каталог сейсмопрогностических наблюдений на территории Азербайджана. - Баку, 2011. - С. 314-321.

25. Каспий: происхожение, геодинамика и стратиграфия / В.Б. Агаев, Г.М. Гусейнов, Ш.Р. Баламедов, Э.Ф. Амиров // Bakı Universitetinin Xəbərləri. - 2006. № 1. - С. $86-101$.

26. Юсубов Н.П. Особенности сейсмичности нефтегазовых областей Азербайджана. - М.: Геофизика, 2012. - № 2. - C. 48-53.

27. Предварительные результаты пересмотра сейсмологических данных Кавказа / В.Ю. Бурмин, И.Б. Шмелева, Л.Д. Флейфель [и др.] [Электронный pecypc]. - URL: ifz.ru〉fileadmin/user_upload/ subdivisions/506/... (дата обращения: 15.05.2017).

28. Яковлев Ф.Л. Владимир Владимирович Белоусов и проблема происхождения складчатости // Геофизические исследования. - 2008. - Т. 9, № 1. - С. 53-73.

29. Расцветаев Л.М., Маринин А.В. Соотношение поверхностной и глубинной структуры северозападного Кавказа [Электронный ресурс]. - URL: resources.krc.karelia.ru/krc/doc... (дата обращения: 15.05.2017).

30. Daly M.C. Correlations between Nazca/Farallon Plate kinematics and forearc basin evolution in Ecuador // Tectonics. - 1989. - 8, № 4. - P. 769-790. DOI: 10.1029/TC008i004p00769

31. Seist E.L., Childs J.R., Scholl D.W. The origin of summit basins of the Aleutian Ridge: Implications for block rotation of an arc massif // Tectonics. - 1988. - 7, № 2. - P. 327-341. DOI: 10.1029/TC007i002p00327

32. Nur A., Ron H., Scotti O. Fault mechanics and the kinematics of block rotation // Geology. - 1986. - 14. - P. 746749. DOI: 10.1130/0091-7613(1986)14<746:FMATKO > 2.0.CO;2

33. Activegeodynamics of the Caucasus region: implications for earthquake hazard assessment in Azerbaijan / F.A. Kadirov, M. Floyd, R. Reilinger, Ak.A. Alizadeh, I.S. Guliyev, S.G. Mammadov, R.T. Safarov // Proc. of Azerbaijan National Academy of Sciences. The Sci. of Earth. - 2015. - № 3. - P. 3-17.

Please cite this article in English as:

Yusubov N.P. Connections between intermediate \& shallow-focus earthquakes and tectonic faults based on data of CDP seismic survey method. Perm Journal of Petroleum and Mining Engineering, 2017, vol.16, no.4, pp.304-312. DOI: 10.15593/2224-9923/2017.4.1

Просьба ссылаться на эту статью в русскоязычных источниках следующим образом:

Юсубов Н.П. О связях очагов промежуточных и мелкофокусных землетрясений с тектоническими разломами по данным сейсморазведки методом общей глубинной точки // Вестник Пермского национального исследовательского политехнического университета. Геология. Нефтегазовое и горное дело. - 2017. - Т.16, №4. - С.304-312. DOI: 10.15593/2224-9923/2017.4.1 